\title{
Applying a Rights-Based Approach to Social Work Practice in Africa: Students' Perspectives
}

Solomon Amadasun

Department of Social Work, Faculty of Social Sciences, University of Benin, Benin-City, Nigeria.

Email:Amadasun.s@yahoo.com

Licensed:

This work is licensed under a Creative Commons Attribution 4.o License.

Keywords:

Rights-based approach

Social work students

Human rights infringements

Social work education

Nigeria

Socialjustice

Social work practice.

Accepted: 27 March 2020

Published: 14 April 2020

\begin{abstract}
The application of a rights-based approach to social work practice is integral to ridding society of social injustice and human rights infringements. As the next generation of social work practitioners in Africa (a continent at the top of the pyramid in human rights violations), what social work students know about the rights-based approach could prove pivotal in preparing them towards entrenching social justice and human rights tenets in their professional practice, as is consistent with the Universal Declaration on Human Rights. This study aims to share the reflections of Nigerian social work students regarding their knowledge of and preparedness to utilize the rights-based approach to social work practice. In employing a qualitative design, semi-structured interviews was conducted among graduating social work students in a large-sized university in Nigeria. Data were subjected to thematic analysis and following the analytical procedure, findings reveal inadequacies in professional social work education and training in the context of equipping students with this practice approach. Although this inquiry involved a cohort of student social workers in their final academic year, the findings may have broader implications for social work education in Nigeria and indeed Africa given the rapidly standardized move in social work education. To offset this trend by means of competency-building, pragmatic suggestions are offered to social work educators with a view to ensuring that social work students are not only equipped in the knowledge of this practice approach but also ready to employ such knowledge to practice.
\end{abstract}

Funding: This research received no specific funding.

Competing Interests: The author declares that there are no conflicts of interests regarding the publication of this paper.

Acknowledgement: Author registers immense gratitude to the anonymous reviewers for their candid and constructive comments, leading to the final draft and publication of the article.

\section{Introduction}

Recent decades has heralded an upsurge in the body of literature within the social work profession with an acute focus on a rights-based approach to practice (Healy \& Link, 2012; Hokenstad \& Midgley, 1997; Ife, 2008; Ife., 2010; Reichert, 2006; Reichert, 2007; Reichert, 2011; Wetzel, 1998; Witkin, 1998). Such inundation of attention in this regard comes as no surprise given the profession's historical value commitment to issues bordering on socioeconomic justice and the liberation and empowerment of people, all of which a rights-based approach typifies and seeks to promote. Such commitment underscores the imperative of mainstreaming a rights-based perspective in social work practice in Africa, a region with a flagship record of human rights violations, reflected in brazen socioeconomic, cultural, and political exclusion, as well as strategic marginalization of minority or powerless groups. As a profession with an unflinching commitment to the social conditions of underprivileged populations, practitioners are ethicallybound to ensure that, in the event of such injustice playing out in environments in which they practice, they act accordingly, either singly or collectively, on behalf of people whose human dignity has been flagrantly stripped and debased. By any standards, acting effectively in this regard requires that social workers demonstrate, before anything else, a firm grasp of the rights-based approach to practice since this approach is most fitting to addressing these issues. Yet, there is no available evidence, to my knowledge, as to whether or 
not social workers are prepared to practice from this perspective on the African continent as a whole and in Nigeria in specific. Consequently, as the next generation of social workers, the focus of this study is to share the reflections of Nigerian social work students regarding a rights-based approach to social work practice.

Significantly, the findings of this research will prove pivotal in strengthening the capacity of social work education in producing competently trained practitioners, grounded in the knowledge and application of a rights-based framework with the outlook of achieving the profession's stated objectives of promoting social justice and ensuring the human rights of all people (National Association of Social Workers (NASW), 2008; Weiss-Gal \& Gal, 2009) regardless of their ethnic, religious, and political affiliations, social status and cultural leanings, and gender orientation. Furthermore, this study will be making an important contribution to the field by including an African perspective- an often marginal voice- to the discourse on the rights-based approach within the social work profession.

The following section briefly considers the literature relevant to the rights-based perspective in social work practice. Next is the description of the research methodology employed and a discussion of students' reflections on the rights-based approach. Before concluding with recommendations for social work education based on the findings of the investigation, the study limitations are pointed out.

\section{Research Pertaining to the Rights-Based Approach in Social Work \\ 2.1. Understanding Human Rights}

According to the United Nations Office of the High Commissioner for Human Rights (2006) a rightsbased approach is a conceptual framework for the process of human development that is normatively premised on international human rights standards and operationally directed to promoting and protecting human rights. Highlighting the universality of rights, Healy (2007) asserts that, 'at the most basic level, human rights are those rights that belong to us all just because we are human' (p.13). According to the United Nations Population Fund (UNFPA) and Harvard School of Public Health (2010) human rights are unlike the rights that citizens possess due to birth or naturalization in any particular country, in that they are universal and internationally guaranteed, in which they can neither be given or taken away even as they impose obligations on States (and other large actors, like corporations) to respect, protect and fulfill them. Human rights, for the most part, are encoded in a body of laws, represented in a bureaucracy, and typified by a field of practice. In principle and practice, they are powerful forces for entrenching social justice. As Moyn (2010) writes, human rights create 'an agenda for improving the world, and bringing about a new [world] in which the dignity of each individual will enjoy secure international protection' (p.1). Scholars and historians acknowledge the evolving expression of human rights in morphing into a rights-based approach, utilizable by helping professions, such as social work in advancing human dignity and social justice (Clapham, 2007; Haas, 2008; Hawkins, 2009; Hawkins, 2010; Healy, 2008; Moyn, 2010).

\subsection{Explicating the Link between Social Work and Human Rights}

Many social work scholars have dispassionately argued that social work has a long history as a human rights profession (Amadasun, 2020; Healy, 2008; Staub-Bernasconi, 2012; Webb, 2009; Weiss-Gal \& Gal, 2009). In advancing their argument, they point to social work reformers such as Jane Addams and Englantyne Webb in the United States and Britain respectively, contending that social workers have proud traditions of advocacy on behalf of vulnerable groups whose rights have been trampled. As Healy (2008) highlights, many social workers have, since the inception of the profession, embraced a human rightsoriented approach in their practice even if they did not apply the term "human rights" to their work. More recently, social work, as represented by its global professional body, has officially embraced human rights, and this is amplified in its recent policy statements and definition of the profession in which the principles of social justice and human rights are underscored as fundamental to the profession (International Federation of Social Workers (IFSW), 2012, 2014; Reichert, 2011; Rodgers, 2009). Similarly, the United States' National Association of Social Workers has reaffirmed the profession's commitment to advancing human rights by reminding practitioners that human rights concerns have been the bedrock of the profession and that, on this score, they must act to advance all aspects of human rights, including -if warranted- supplementing civil or political rights with social, economic, and cultural rights (NASW, 2012). Even without these explicit statements, it has been identified that social work's code of ethics is amenable with human rights dictates and language (Amadasun, 2020; Androff, 2010; Buchanan \& Gunn, 2007; Reichert, 2011; Skegg, 2005).

\subsection{Why a Rights-Based Approach to Social Work Practice?}

It has been vehemently argued that the broad reach of human rights- encompassing education, healthcare, employment, and housing, as well as political and legal inequalities- has the potential to create philosophical and political power that the narrower category of civil rights lack (Anderson, 2003). In elaborating this point, Gude (2013) writes:

'The discourse of rights [is a discourse] of human agents claiming what's theirs instead of asking permission from the powerful... dignity, not charity, is the animating principle. People earn access to the rudiments of life (food, healthcare, shelter) by virtue of their humanity. Rights 
language invites the beggar to rise from his knees and, without equivocation or supplication, demand his humanity be recognized. Workers are entitled to a living wage. Children are entitled to grow up free from poverty, [and] homeless people are entitled to a home' (p.1).

In highlighting the prospects of amplifying and employing a rights-based approach to practice, Jochnick (1999) provides a vivid description in asserting that:

'The real potential of human rights lies in its ability to change the way people perceive themselves vis-à-vis the government and other actors. A rights framework provides a mechanism for reanalysing and renaming 'problems' like contaminated water or malnutrition as 'violations' and, as such, something that need not and should not be tolerated... rights make it clear that violations are neither inevitable or natural, but arise from deliberate decisions and policies. By demanding explanations and accountability, human rights expose the hidden priorities and structures behind violations and challenge the conditions that create and tolerate poverty' (p.59)

The rapidly expanding social work scholarship on human rights largely concurs with Anderson (2003); Gude (2013) and Jochnick (1999) conception, as well as suggests that a human rights orientation to practice could catalyse the profession's ability to fulfil its social justice mission. Explicitly, scholars such as Engstrom and Okamura (2005); Lundy (2011); Amadasun, (2020); Mapp (2008) and Zaviršek and Herath (2010) posit that a rights-based approach underpins social justice by reducing the focus on individual pathology (as is typical of clinical or residual practice) and by demanding that individual problems be seen in a socio-political and/or structural contextual frame. Others theorize that this approach is empowering for service users, in that it redefines their needs as an entitlement or rights for which duty-holders are obligated to comply (Cemlyn, 2011; Hancock, 2007; Lundy \& Wormer, 2007). More so, a rights-based perspective gives social workers powerful tools for educating service users, communities, and themselves about inequities and inequalities, and the larger social structures (Barrett, 2011; Weiss-Gal \& Gal, 2009). At a broader level, Healy (2008) advocates that applying a rights-based approach to practice will enable social workers to bridge 'local and national issues with global concerns' (p. 745), from where the profession can reorganize itself as a truly global profession in a world of rapid global migration and neoliberal capitalism (Hawkins, 2009; Lundy, 2011; Reichert, 2003; Wetzel, 1998; Wronka \& Staub-Bernasconi, 2012). Lastly, a rights-based approach has been construed as being capable to offer social work the opportunity to assume leadership role by becoming the point profession on economic, social, and cultural rights (Dominelli, 2007; Ife, 2008; McPherson, 2014; Noyoo, 2004; Weiss-Gal \& Gal, 2009; Yu, 2006).

\section{Aim of the Study}

The aim of this study is to share the reflections of Nigerian social work students in relation to (1) how they conceptualize the rights-based approach to practice, (2) their experience of the rights-based approach relative to their education and training, and (3) how they intend to practice from a rights-based perspective upon graduation.

\section{Methodology}

4.1. Research Design

A qualitative evaluation research design was used in this study. Babbie and Mouton (2001) discuss the relevance of evaluation research in developing countries, such as Nigeria, that is interested in assessing whether or not, for instance, the quality of social work education in the country is consistent with international best standards in terms of producing competently trained social workers who are well grounded in the knowledge and application of a rights-based approach to social work practice. Drawing on this research design, therefore, enabled the researcher to identify the strengths and weaknesses of social work education in Nigeria. More so, a qualitative approach to the gathering of data was utilized because the 'data that was needed was descriptive and exploratory, and information was required directly from people who were assumed to have the required information' (Hofstee, 2009).

\subsection{Sample and Procedure}

The participants in this study comprised of fourth-year undergraduate social work students in one major university in southern Nigeria. Students in their final academic year were purposively recruited because they have undergone almost all the courses in the bachelor's (BSW) program, and were on the verge of graduating from the social work department and getting set for practice. Before the commencement of this study, flyers were posted in strategic locations within the social work department, including the departmental notice board, in which the objectives of the study were boldly highlighted and students were invited to participate. Through this procedure, 16 students of a total of 45 final year students indicated interest to participate in the study. However, at the scheduled date for the commencing of the investigation, 4 students withdrew their consent, thereby bringing the total study participants to 13 student social workers, comprising of 9 female and 4 male students. Such composition comes as no surprise as it reflects the widely held view of social work as a 'female' dominated profession (Earle, 2008). 


\subsection{Data Collection and Analysis}

A semi-structured interview schedule based on one-on-one interviews was employed as a means of data collection. Before the commencement of the exercise, a pilot study was organized among a group of thirdyear students to check for vagueness regarding the questions. The students reported no ambiguity and, as such, no alteration was made. As Hofstee (2009) notes, interviews conducted in a relaxed atmosphere work well to build rapport and authenticity. To that end, the interview was conducted in the department's conference room and lasted 20-30 minutes each. Data saturation (Bowen, 2008) was observed after ten interviews, leading to the termination of the two outstanding interviews.

Data were analysed according to the steps intrinsic to Interpretive Phenomenological Analysis (IPA). In this regard, transcripts of the interviews were written up and analysed, and themes were identified and connections made between transcripts to develop a set of master cross-transcript themes (Houston \& Mullan-Jensen, 2011). Reliability and authenticity are important in qualitative research and strategies such as recording data objectively and comprehensively, a count of events, and the use of audio tapes assist in ensuring rigor and validity (Seale \& Silverman, 1997). The six steps as suggested by Smith, Flowers, and Larkin (2009) was followed in the course of the data analysis: (1) reading and re-reading, (2) initial noting, (3) developing emerging themes, (4) searching for connections across emergent themes, (5) moving to the next case, and (6) looking for patterns across cases. As a further step to ensuring the validity of the qualitative data, Maxwell's five validity categorization in qualitative research was used (Maxwell, 2008). Descriptive validity is based on an attempt to accurately describe the data by means of transcripts of verbatim responses. In this regard, no information was left out or altered and the use of an integrated independent coder also contributed to descriptive validity. Interpretive validity was ensured by the use of the transcript that included both the verbal and non-verbal data to justify interpretations. The use of a purposive sampling technique and a thorough description of the implementation of the research methodology ensured the transferability of the findings to other similar contexts. To ensure theoretical validity, a literature control was done once the themes and sub-themes were identified through data analysis. Evaluative validity was achieved by ensuring that the evaluation was based on the findings that emanated from the process of data analysis. Overall, following these steps was a time-consuming but valuable process in ensuring reliability and rigor throughout the research process.

\subsection{Ethics}

In addition to the approval by the social work department to conduct this study, ethical approval was equally sought and secured by the author's university research and ethics committee. Ethical issues addressed in this study include informed consent, voluntary participation, and privacy and protection from harm. Accordingly, identifying details of the participants and the institution in which they represent are anonymized. Furthermore, their responses are presented as a collective story to further obscure individual identification.

\section{Results}

The result is presented on the basis of the three themes see Table 1 that emerged from the qualitative data: conceptualizing rights-based approach, rights-based perspective in professional education, and practicing from a rights-based perspective; and they are illustrated with verbatim responses of the student social workers in order to allow their voices to be heard.

Table-1. Thematic framework for the results.

\begin{tabular}{l|l}
\hline Theme & Theme \\
\hline Conceptualizing rights-based social work. & $\begin{array}{l}\text { Rights-based social work as mainstreaming problem } \\
\text { issues as rights violations. }\end{array}$ \\
\hline Rights-based perspective in professional education. & $\begin{array}{l}\text { Rights-based social work as a platform for achieving } \\
\text { all-embracing social justice. }\end{array}$ \\
\hline Applying a rights-based approach to practice. & $\begin{array}{l}\text { Limited field practice experience. } \\
\text { practices human rights infringements. }\end{array}$ \\
\hline & $\begin{array}{l}\text { Engaging in human rights activism through } \\
\text { education and consciousness-raising. }\end{array}$ \\
\hline & $\begin{array}{l}\text { Liaising } \\
\text { organizations and professions. }\end{array}$ \\
\hline
\end{tabular}

\subsection{THEME 1: Conceptualizing Rights-Based Social Work}

As a first step in exploring their views, the participants were requested to reflect on the term "rightsbased social work" and share the meanings they could deduce from it. Drawing insights from the phrase, they construed rights-based social work as a practice approach that enables social workers to mainstream problem 
issues as rights infringement issues. They equally considered rights-based social work as allowing for the prioritization of all rights, including political, social, economic, and cultural rights. One student explains, ' $a$ rights-based social work practice underscores the imperative of ensuring that social problems are not just called that but that they become rights issues... with that being the case, rights-based social work enables us to see poverty and gender violence, for example, as human rights violations from where we can demand justice and not just as social problems'. Another student asserts that 'rights-based social work is about demanding what belongs to the people so that they can live a life of decency and dignity... it kicks against begging for what is rightfully yours'.

\subsection{THEME 2: Rights-Based Perspective in Professional Education}

Regarding the degree to which a rights-based approach was embedded in their professional education and training as exemplified by their class instruction and fieldwork, the participating students expressed satisfaction with the inclusion of the course "law and rights-based social work" in their curriculum. They, however, pointed out one key issue that has not gained prominence in the course content: knowledge about legislation and provisions of the law about pressing social problems. They argued that without such knowledge they may not be able to effectively apply a rights-based approach to practice. One student comments, 'since a rights-based social work is about challenging social injustice from a legal angle, it makes perfect sense that we are enlightened about provisions of the law against human trafficking, child labor, and gender-based violence for example, so that we will be able to advocate on behalf of our service users... I am not saying we have to become lawyers, my point is if we are to become effective in this approach, we need to be informed about laws and the course has not addressed this'.

Pertaining to their field practice experience, all but two of the participants were unanimous in their assertions that they did not receive adequate field experience concerning practicing in human rights-based organizations. While acknowledging their anticipation of such practice opportunity, they, however, expressed dissatisfaction that they were hurriedly assigned to majorly statutory human service agencies whose goals are at variance with the tenets of a rights-based social work. Pointedly, they wondered why they got drafted to such agencies despite the preponderance of human rights-allied voluntary organizations whose goals are amenable to the underlying principles of rights-based social work. As one student utters, 'I thought field practicum training is supposed to be structured in such a way as to merge students' interest with agencies' goals... in our case, it was just disappointing, like putting a square peg in a round hole'. Another student notes, 'several human rights agency abound so that we can integrate out theoretical knowledge with actual practice, yet I got posted to a government agency where their goals of the agency was not only incompatible but, I must say this, also against the principles of social justice which a rights-based social work aims to achieve'.

\subsection{THEME 3: Practicing From a Rights-Based Perspective}

In light of their impressive conceptual clarification of a rights-based approach, the participants were urged to reflect on how they intend to practice from this perspective following the completion of their degree program. While a majority of the participants commented in this regard, two of the participants who had conducted their field placement training in an advocacy group which relies heavily on a human rights framework specifically shed more light in this discourse by identifying three practice strategies utilizable in applying a rights-based approach. First, they spoke of framing discriminatory and oppressive policies and practices as human rights violations and that being overly abreast with social policies and engaging in policy advocacy is one strategy employed by rights-based practitioners. As one of the students pointed out, 'from experience, I can say that several anti-people policies have been proposed by authorities at all level but these policies are defeated as a result of the foresight of social workers who often work collaboratively with lawyers...yet, it is amazing that most of the citizens are not even aware of this reality. Second, they posit that practicing from a rights-based perspective requires engaging in human rights activism through public enlightenment campaigns and consciousness-raising. However, proficiency in the provisions of the law, they purport, is a recipe for success. One student clarifies, 'success in human rights activism, as far as rights-based social work is concerned, necessitates the imperative of acquiring knowledge about legislation so that infringement can be easily and quickly identified'. Third, the students conclude that integral to applying a rights-based approach to social work practice is the inevitability of liaising with organizations and professions who are committed to the protection and advancement of human rights of all people especially those of dehumanized and deprived populations.

\subsection{Limitations of the Study}

The major limitation of this study is relative to the small sample size of the research participants. Although consistent with the norms in qualitative research, the sample size limits the prospects of generalizability of the research findings. This notwithstanding, this study has made an indelible contribution to the limited body of literature on social work education in Nigeria and indeed Africa. As an exploratory study, this study may become a reference point for future research of not only social work education but on the discourse on rights-based social work practice in the continent. 


\section{Discussion}

The findings of this study pertaining to how the students conceptualized a rights-based approach to social work practice correspond with the existing literature (Androff \& McPherson, 2014; Barrett, 2011; Calma \& Priday, 2011; Gude, 2013; Lundy, 2011; McPherson, 2013; Reichert, 2011). United Nations Office of the High Commissioner for Human Rights (2006) submits that the main purpose of implementing a rightsbased approach is to protect human rights. He adds that inherent to this approach are five principles: express to linkage (that is, mainstreaming problem issues through the instrument of the legal framework), accountability, empowerment, participation, and non-discrimination but prioritization of vulnerable groups.

The finding pertaining to the degree to which anti-oppressive practice was embedded in social work education and training may be explained by revisiting some pertinent issues and trends relative to social work education in Nigeria. This, however, would be summarily highlighted due to the paucity of space. Amadasun (2020) notes that professional social work training in Nigeria began in 1976 at the University of Nigeria, Nsukka through the influence of a sequence of international surveys conducted by the United Nations in collaboration with the Nigerian government who, at the time, were concerned with the advancement of social development as was exemplified by Decree 12 of 1974 which prioritized social development in all public parastatals across the country. Although the then social work unit under the department of sociology was charged with the mandate of producing development-inclined practitioners, this responsibility fell short of expectations since most of the social work educators were trained in the West in which the residual or casework model overrode other training methods (Amadasun, 2020). By implication, social work education since its inception in the country has been characterized by the overwhelming reliance on the curative model as the means of educating practitioners. However, about a decade ago, social work education in Nigeria has experienced a major change in its curriculum content, following repeated calls by some scholars (see Anucha (2008)). As a consequence, through the Social Work in Nigeria Programme (SWIN-P)- a joint partnership involving three Canadian universities (York University, University of Windsor, and University of British Columbia) and a Nigerian university (University of Benin, Benin-City.); social work education and training has now fully embraced a generalist model in which the person-inenvironment paradigm is prioritized, allowing for the utilization of both micro, mezzo, and macro level models and intervention strategies. Implicit in the preceding is the inclusion of several social justice-oriented approaches, such as rights-based practice, to the training and education of social workers in the country. Since this approach to training is relatively novel, it is not surprising therefore that the participants, while appreciating the course, seemed dissatisfied with the lack of pertinent issues in the course content.

The finding pertaining to the suggestions of the students regarding how they intend to practice from a rights-based perspective corroborates the professional literature (Barrett, 2011 ; Engstrom \& Okamura, 2005; Hancock, 2007; Mapp, 2008; McPherson, Chiarelli-Helminiak, Libal, \& Harding, 2013; Wronka, 2008; Zaviršek \& Herath, 2010). Pointedly, Mapp (2008) notes that practicing from a rights-based approach requires social workers to intervene across levels since 'we are equipped to work in the micro level with the victim and also on the macro level to stop the conditions that create the atmosphere' that perpetuates rights violations (p.48). Her suggestions also feature securing partnership with human rights experts, professionals, and organizations.

On the surface, the findings of this study demonstrate that social work students are not only knowledgeable about a rights-based perspective, but are equally well-poised to practice from this approach. However, such interpretation should be exercised with caution since two of the participating students (who had undergone field practice in human rights-allied organizations) offered the bulk of these insights. Thus, the reverse may have been the case had they not undergone their block placement in such agencies. This situation has yet again underscored the imperative of field practicum training to social work education, and it is in this light that the implication of this study would be majorly directed at enhancing the quality of field training, as a cardinal aspect of social work education, in Nigeria.

\section{Implications for Social Work Education}

Following the findings of this study especially in reference of anti-oppressive practice in social work education, the following suggestions are offered to social work educators in Nigeria with the outlook of strengthening the depth of anti-oppressive discourse in both classroom instructions and field placement training with the aim of enhancing the formidability of social work education and training in the country and, by extension, in the continent.

1. As conveyors of social work knowledge, skills, and values, social work educators must realize that equipping students with a profound understanding of a rights-based approach that would result in action in the context of their utilization of this practice model, must be accompanied with the knowledge of the law. This is all the more important given the long existing connections between social work and law. Pointedly, in the design of the course contents on rights-based social work, educators should include and deliver modules that detail specific legal provisions about pertinent social problems in the country. This way, students would not overly become saturated with abstract concepts but they would also become acquainted with concrete actions to pursue when the rights of 
their service users have been infringed. In short, this knowledge would drastically reduce the prospects of social workers in becoming helplessly dependent on the legal profession for the interpretation of the law before proceeding to embark on human rights advocacy.

2. As the signature pedagogy of social work education (CSWE, 2008) the import of field practice training cannot be overemphasized. As Bogo (2015) dispassionately points out, 'the ability of social work education to graduate ethical, competent, innovative, effective clinical social workers is highly dependent on the quality of the field experience' (p.317). Consequently, administrators of schools and/or department of social work in Nigeria should, as a matter of urgency, expedite action towards ensuring that their field practice training embraces all practice approaches and orientations in the social work profession and not overly tilted to assigning students to agencies who rely on one practice model. Furthermore, the field education unit in the department of social work across the country should be open to consultations with student social workers before they are assigned to practice in any agency or organization. After all, research has shown that social work students involvement regarding field practicum sites contribute to the success of field experience (Domakin, 2014; Fortune \& Abramson, 1993).

3. In situations in which there are inadequate social service agencies within the field education unit of the social work department, collaborations should be sought and secured from and among the multitudes of both statutory and voluntary human service organizations within the country. Such a contract should be premised on a mutual understanding that creates a safe and effective learning environment for students so they could enhance their knowledge from the field while consolidating the theoretical foundations of such organizations.

\section{Suggestions for Further Research}

Given the ostensible dearth of literature on this subject area, combined with the accelerating pace of social work's growth and development in Nigeria, it is expedient therefore that further research be conducted in this regard in order to develop and broaden the literature of social work generally in the country, as well as to ensure that social work education live up to international best practice standards of graduating competent practitioners who are equipped with not only the knowledge of a rights-based approach but other social-justice-oriented practice so that they can help address personalized and structural challenges faced by individuals, families, groups, organizations, and communities in the country. Such future research is not exclusive to social work researchers alone as research is equally a responsibility for all social work professionals (educators, practitioners, and students). In the context of a rights-based practice, research endeavour could be geared towards exploring whether or not social workers apply this approach in their daily practice in the country, as exploring their experiences would help to promote and enhance the quality of a rights-based approach to social work practice in Nigeria. By doing this, the profession would be meeting its historical value commitment to social justice and human rights from where its relevance in the country and indeed Africa would be truly appreciated and unchallenged.

\section{References}

Amadasun, S. (2020). Social work for social development in Africa. Ibadan: September Publishing House.

Anderson, C. E. (2003). Eyes off the prize: The United Nations and the African American struggle for human rights, 1944-1955. Cambridge, UK: Cambridge University Press.

Androff, D. K. (2010). Truth and reconciliation commissions (TRCs): An international human rights intervention and its connection to social work. British Journal of Social Work, 40(6), 1960-1977.Available at: https://doi.org/10.1093/bjsw/bcp139.

Androff, D., \& McPherson, J. (2014). Can human rights-based social work practice bridge the micro/macro divide? In K. R. Libal, S. M. Berthold, R.L. Thomas and L. M. Healy (Eds.). Advancing Human Rights in Social Work Education. Washington, DC: Council on Social Work Education.

Anucha, U. (2008). Exploring a new direction for social work education and training in Nigeria. Social Work Education, 27(3), 229-242.Available at: https://doi.org/10.1080/02615470701381459.

Babbie, E., \& Mouton, J. (2001). The practice of social research. Southern Africa: Oxford University Press.

Barrett, J. A. (2011). Multicultural social justice and human rights: Strategic professional development for social work and counseling practitioners. Journal for Social Action in Counseling \& Psychology, 3(1), 117-123.

Bogo, M. (2015). Field education for clinical social work practice: Best practices and contemporary challenges. Clinical Social Work, 43(1), 317-324.Available at: 10.1007/s10615015-0526-5.

Bowen, G. A. (2008). Naturalistic inquiry and the saturation concept: A research note. Qualitative Research, 8(1), 137152.Available at: https://doi.org/10.1177/1468794107085301.

Buchanan, I., \& Gunn, R. (2007). The interpretation of human rights in English social work: An exploration in the context of services for children and for parents with learning difficulties. Ethics and Social Welfare, 1(2), 147162.Available at: https://doi.org/10.1080/17496530701450349.

Calma, T., \& Priday, E. (2011). Putting indigenous human rights into social work practice. Australian Social Work, 64(1), 147-155.Available at: 10.1080/0312407X.2011.57592.

Cemlyn, S. (2011). Human rights practice: Possibilities and pitfalls for developing emancipatory social work. Ethics and Social Welfare, 2(1), 222-242.Available at: 10.1080/17496530802481714. 
Clapham, A. (2007). Human rights: A very short introduction. New York: Oxford University Press.

CSWE. (2008). Educational policy and accreditation standards. Alexandria, VA: Author.

Domakin, A. (2014). Are we making the most of learning from the practice placement? Social Work Education, 33(6), 718730.Available at: https://doi.org/10.1080/02615479.2013.869315.

Dominelli, L. (2007). Human rights in social work practice: an invisible part of the social work curriculum?” In E. Reichert (Eds.). Challenges in human rights: A social work perspective (pp. 16-43). New York: Columbia University Press.

Earle, N. (2008). Social work as a scarce and critical profession. South Africa: Research Commissioned by the Department of Labour.

Engstrom, D., \& Okamura, A. (2005). A plague of our time: Torture, human rights, and social work. Families in Society, 85(1), 291-300.Available at: 10.1606/1044-3894.1509.

Fortune, A. E., \& Abramson, J. S. (1993). Predictors of satisfaction with field practicum among social work students. The Clinical Supervisor, 11(1), 95-110.Available at: https://doi.org/10.1300/j001v11no1_07.

Gude, S. (2013). In defense of 'entitlements.' Jacobin: A magazine of culture and polemic. Retrieved from: https://www.jacobinmag.com/2013/12/in-defense-of-entitlements/.

Haas, M. (2008). International human rights: A comprehensive introduction. London, UK: Routledge.

Hancock, T. U. (2007). Come the revolution: human rights, the far right, and new directions for social work education. The Journal of Baccalaureate Social Work, 12(2), 1-12.Available at: https://doi.org/10.18084/1084-72 19.12.2.1.

Hawkins, C. A. (2009). Global citizenship: A model for teaching universal human rights in social work education. Critical Social Work, 1O(1), 116-131.

Hawkins., C. A. (2010). Sustainability, human rights, and environmental justice: Critical connections for contemporary social work practice. Critical Social Work, $11(3), 68-81$.

Healy, L. M. (2007). Universalism and cultural relativism in social work ethics. International Social Work, 50(1), 1126.Available at: 10.1177/0020872807071479.

Healy, L. M. (2008). Exploring the history of social work as a human rights profession. International Social Work, 51(6), 735-748.Available at: https://doi.org/10.1177/0020872808095247.

Healy, L. M., \& Link, R. J. (2012). Handbook of international social work: Human rights, development, and the global profession (Eds.). New York: Oxford University Press.

Hofstee, E. (2009). Constructing a good dissertation: a practical guide to finishing a master's MBA or Ph.D. on schedule. South Africa: Epee.

Hokenstad, M. C., \& Midgley, J. (1997). Issues in international social work: Global challenges for a new century (Eds.) Washington, D.C: NASW Press.

Houston, S., \& Mullan-Jensen, C. (2011). Towards depth and width in qualitative social work: Aligning interpretative phenomenological analysis with the theory of social domains. Qualitative Social Work, $11(3), 266-281$.

Ife, J. (2008). Human rights and social work: Towards rights-based practice. Cambridge, UK: Cambridge University Press.

Ife., J. (2010). Human rights from below: Achieving rights through community development. Cambridge, UK: Cambridge University Press.

International Federation of Social Workers (IFSW). (2012). Human rights. Retrieved from: https://www.ifsw.org/whatis-social-work/global-definition-of-social-work/.

International Federation of Social Workers (IFSW). (2014). Global definition of social work. Retrieved from: https://www.ifsw.org/what-is-social-work/global-definition-of-social-work/.

Jochnick, C. (1999). Confronting the impunity of non-state actors: New fields for the promotion of human rights. Human Rights Quarterly, 21(1), 56-79.Available at: 10.1353/hrq.1999.0008.

Lundy, C. (2011). Social work, social justice, and human rights: a structural approach to practice (2nd ed.). Toronto, CA: University of Toronto Press.

Lundy, C., \& Wormer, v. K. (2007). Social and economic justice, human rights and peace: The challenge for social work in Canada and the USA. International Social Work, 50, 727-739.Available at: 10.1177/0020872807081899.

Mapp, S. C. (2008). Human rights and social justice in a global perspective: An introduction to international social work. New York: Oxford University Press.

Maxwell, J. A. (2008). Qualitative research design: An interactive approach (3rd ed.). Thousand Oaks: Sage Publications.

McPherson, J. (2014). Human rights practice in social work: a U.S. social worker looks to Brazil for leadership. European Journal of Social Work, 1(1), 1-14.Available at: 10.1080/13691457.2014.947245.

McPherson, J. (2013). Human rights exposure, knowledge, and engagement: What do US social work students really understand? Paper presented at the A Paper Presented at the National Association of Deans and Directors (NADD)'s Annual Conference: Global Health and Well-Being: The Social Work Response. New York. June.

McPherson, J., Chiarelli-Helminiak, C., Libal, K., \& Harding, S. (2013). Applying human rights principles to U.S. social work practice through interdisciplinary collaboration. Paper presented at the A Paper Presented at Council on Social Work Education Annual Program Meeting in Dallas, Texas.

Moyn, S. (2010). The last utopia: Human rights in history. Cambridge, Massachusetts: The Belknap Press of Harvard University.

NASW. (2012). International policy on human rights, In Social Work Speaks: National Association of Social Workers Policy Statements (9th ed., pp. 2012-2014). Washington, DC: Author.

National Association of Social Workers (NASW). (2008). Code of ethics of the national association of social workers. Washington, DC: Author.

Noyoo, N. (2004). Human rights and social work in a transforming society: South Africa. International Social Work, 47(1), 359-369.Available at: 10.1177/0020872804043961.

Reichert, E. (2006). Understanding human rights: An exercise book. Thousand Oaks, CA: Sage Publications.

Reichert., E. (2007). Challenges in human rights: A social work perspective. New York: Columbia University Press. 
Reichert, E. (2011). Social work and human rights: A foundation for policy and practice (2nd ed.). New York: Columbia University.

Reichert, E. (2003). Viewing human rights and social work through an international perspective. Journal of Intergroup Relations, 30(1), 76-83.

Rodgers, J. A. (2009). Global social work practice, human rights, social work ethics and human responsibilities: The challenge. Journal of Global Social Work Practice, 2(2), 11.

Seale, C., \& Silverman, D. (1997). Ensuring rigour in qualitative research. The European Journal of Public Health, 7(4), 379-384.

Skegg, A.-M. (2005). Brief note: Human rights and social work: A western imposition or empowerment to the people? International Social Work, 48(5), 667-672.Available at: https://doi.org/10.1177/0020872805055334.

Smith, J. A., Flowers, P., \& Larkin, M. (2009). Interpretative phenomenological analysis: Theory, method and research. London: Sage Publications.

Staub-Bernasconi, S. (2012). Human rights and their relevance for social work as theory and practice" In Healy, L. M. and Link, R. J. (Eds.), Handbook of international social work: human rights, development and the global profession. New York: Oxford University Press.

United Nations Office of the High Commissioner for Human Rights. (2006). International convention for the protection of all persons from enforced disappearance. Retrieved from: http://www.ohchr.org/EN/HRBodies/CED/Pages/ConventionCED.aspx.

United Nations Population Fund (UNFPA) and Harvard School of Public Health. (2010). A human rights-based approach to programming: practical implementation manual and training materials. Retrieved from: http://www.unfpa.org/public/op/preview/home/publications/pid/4919.

Webb, S. A. (2009). Against difference and diversity in social work: The case of human rights. International Journal of Social Welfare, 18, 307-316.Available at: 10.1111/j.1468-2397.2009.00659.x.

Weiss-Gal, I., \& Gal, J. (2009). Realizing rights in social work. Social Service Review, 83(2), 267-291.Available at: https://doi.org/10.1086/599982.

Wetzel, J. W. (1998). Human rights values: An international challenge to social work. Paper presented at the Paper Presented at the 15th Annual Social Work Day at the United Nations, New York, at the International Association of Schools of Social Work Symposium, March 25.

Witkin, S. L. (1998). Human rights and social work. Social Work, 43(3), 197-201.

Wronka, J., \& Staub-Bernasconi, S. (2012). Human rights” In Lyons, K., Hokenstad, T., Pawar, M., Huegler, N. and Hall, N. (2012). The Sage handbook of international social work (pp. 70-84). Los Angeles, CA: SAGE.

Wronka, J. (2008). Human rights and social justice: Social action and service for the helping and health professions. Los Angeles: Sage Publications.

Yu, N. G. (2006). Interrogating social work: Philippine social work and human rights under martial law. International Journal of Social Welfare, 15(3), 257-263.Available at: https://doi.org/10.1111/j.1468-2397.2006.00401.x.

Zaviršek, D., \& Herath, S. M. (2010). I want to have my future, I have a dialogue’: Social work in Sri Lanka between Neocapitalism and human rights. Social Work Education, 29(8), 831-842.Available at: https://doi.org/10.1080/02615479.2010.516987. 